\title{
Compliance with Personal Protective Equipment Use among Non- Medical Healthcare Professionals during Covid-19 Pandemic
}

\author{
Estika Mei Diana $^{1,2}$, Anna Wahyuni Widayanti1 ${ }^{*}$, Satibi1 $^{1}$
}

1. Department of Pharmaceutical Technology, Faculty of Pharmacy, Universitas Gadjah Mada, Sekip Utara 55281 Yogyakarta, Indonesia,

2. Department of Pharmacy, Saiful Anwar General Hospital, Klojen, Malang City, East Java 65119 Indonesia

\begin{tabular}{l}
\hline Info Article \\
\hline Submitted: 06-01-2021 \\
Revised: 20-05-2021 \\
Accepted: 14-06-2021 \\
\\
${ }^{*}$ Corresponding author \\
Anna Wahyuni Widayanti \\
Email: \\
wahyuni_apt@ugm.ac.id
\end{tabular}

ABSTRACT

Non-medical healthcare professionals, including pharmacists, pharmacy technicians, nutritionists, and radiographers, have a high risk of COVID-19 infection during work. Personal protective equipment use has shown effective in preventing virus transmission. This study aimed to investigate the compliance with personal protective equipment use and identify the factors that may influence users' compliance. The study was designed cross-sectionally, with a self-administered questionnaire. The respondents were non-medical healthcare professionals recruited from covid and non-covid ward at Saiful Anwar General Hospital. The data were collected in November 2020. The questionnaire consists of four questions to assess compliance and eighteen questions to explore factors that may be related to their compliance. This study used the Chi-square test to differentiate the level of compliance between two groups and binary logistic regression to analyze factors that may influence the compliance. Most participants in this study were female (84.8\%), with a median age of 33 (23 - 57) years. More than $80 \%$ of participants worked in the non-covid ward. Only one-fifth of participants had work experience of more than 15 years. The compliance with personal protective equipment was $67.3 \%$. From univariate analysis, factors that influenced the compliance were difficulty using, removing, and disposing of personal protective equipment, lack of training and regular monitoring, unsure feeling about the effectiveness of personal protective equipment, discomfort in donning personal protective equipment. Co-workers never reminding themselves to use personal protective equipment also influenced compliance. From multivariate analysis, the difficulty in using, removing, and disposing of personal protective equipment (OR $2.83(0.730-3.478)$, $\mathrm{p}=0.025)$ significantly influenced compliance with personal protective equipment use.

Keywords: Personal protective equipment, compliance, non-medical healthcare professionals

\section{INTRODUCTION}

Coronavirus Disease (COVID-19), a very infectious disease caused by the new Coronavirus 2 (SARS-CoV-2), was first found in December 2019 in Wuhan City, China (Hozhabri et al., 2020). The virus had spread worldwide, and World Health Organization (WHO) has determined a pandemic status since March 11, 2020 (World Health Organisation, 2020). At the end of November 2020, there have been more than 61.8 million cases and 1.4 million deaths reported around the world
(World Health Organization, 2020). There have been 586,842 cases in Indonesia, with 18,000 deaths reported on December 8, 2020, and the cases had increased rapidly to 8,369 positive cases per day (STPC19, 2021).

During the COVID-19 pandemic, healthcare workers experienced a severe impact. A survey on 37 nations showed that the median of healthcare workers' death was 0.05 per 100,000 populations (Erdem \& Lucey, 2021). By the end of 2020, 507 Indonesian healthcare professionals died due to 
covid-19, with the highest rate in December 2020 (Jahawir Gustav Rizal, n.d.).

The consistent use of personal protective equipment is critical to reducing viral transmission risk because the virus spreads mainly through droplets and direct contact (Verbeek et al., 2020). A meta-analysis study provided evidence of the protective effect of masks and respirators against severe acute respiratory syndrome (SARS) (Offeddu et al., 2017). According to WHO guidelines, all healthcare workers directly involved in patient care at hospitals should use appropriate personal protective equipment (PPE) according to different levels of the workplace (WHO, 2020). This recommendation should be applied by not only doctors and nurses, but also non-medical healthcare professionals involved in patient care including pharmacists, pharmacy technicians, nutritionists, and radiographers. However, these non-medical healthcare professionals generally pay less attention to the recommendation as they may feel safe because their contact with patients is not as intensive as doctors' or nurses'.

Monitoring the compliance of health workers in using PPE plays an essential role in mitigating the risk of infection (Bielicki et al., 2020). Identification of the factors that influence compliance is also an important step to increase compliance. The study on compliance in using PPEs in non-medical healthcare professionals is limited. Houghton et al. showed that compliance in infection prevention is affected by driving and inhibiting factors. The driving factors include fear of infecting themself and their families and responsible feelings for their patients. The inhibiting factors include their lack of confidence in the local guidelines, discomfort, the bad stigma of patients, work culture, management support, lack of PPE quality and quantity (Houghton et al., 2020). A cross-sectional study at a private hospital in Malang showed that less than $60 \%$ of nurses who served Covid-19 patients complied with the use of PPE (Gunawan \& Chalidyanto, 2020). Therefore, we conducted a study to examine non-medical healthcare professionals' compliance and identify the factors that may influence their compliance in using PPE.

\section{MATERIAL AND METHODS Study setting}

The study was conducted at the Saiful Anwar General Hospital (SAGH), the third referral hospital in East Java Province which is located in Malang district. The hospital has approximately a thousand beds, with 2,811 healthcare workers, including 188 medical staff. Almost one-half of healthcare workers are non-medical professionals. The hospital served about 40,000 inpatients, 400,000 outpatients, and 30,000 emergency cases every year (Santoso, 2019). When the Covid-19 pandemic occurred, a VIP ward known as "Graha Puspa Husada" was converted into a COVID ward named INCOVIT. As a reference hospital for COVID-19, It has 103 beds for COVID-19 (Sasongko, 2020).

\section{Study design and period}

This study used a cross-sectional study design that was performed from November 1 to 30 , 2020.

\section{Inclusion / exlusion criteria}

Participants included in this study were nonmedical healthcare professionals, including pharmacists, pharmacy technicians, nutritionists, and radiographers who were willing to participate, directly involved in healthcare services, and aged 20 - 58 years. Participants who were not directly involved in healthcare services and unable to use the google form questionnaire were excluded.

\section{Sample size determination}

The total number of non-medical healthcare professionals in the hospital was 275 , consisting of 53 pharmacists, 116 pharmacy technicians, 66 nutritionists, and 40 radiographers. The sample size was determined with the Slovin formula $\left(\mathrm{n}=\frac{N}{1+N \cdot e^{2}}\right)$ because the population is known (Tejada \& Punzalan, 2012). The sample size was $\mathrm{n}=\frac{275}{1+275 \times 0.05^{2}}=162.96 \cong 163$. We further calculated the sample size for each profession based on its proportion $\quad\left(\mathrm{n}-\right.$ proffesion $\left.=\frac{N \text { total population }}{N \text { profession population }} \times n\right)$. The sample size for pharmacists, pharmacy technicians, nutritionists dan radiographers were $31,69,39$, and 24 , respectively.

\section{Data collection instrument}

Data were collected using an online questionnaire distributed via a google form. When we designed this study, we found no previous research assessing the compliance of non-medical healthcare professionals in using PPE and factors influencing their compliance. Therefore, the questionnaire we used was self-developed based on the literature available. To measure the level of compliance, the questions were developed based on Indonesian Minister of Health guidelines about technical instruction for PPE in facing the COVID- 
19 outbreak (Kementerian Kesehatan RI, 2020). To identify factors affecting compliance, questions were developed based on results of a review about barriers and facilitators of healthcare workers adherence with infection prevention control guidelines for respiratory infectious diseases conducted by Houghton et al. (Houghton et al., 2020).

The questionnaire includes three sections. In the first section, the questions were about participant's demographic characteristics. The second section of the questionnaire contained four questions asking participants' compliance in using PPE including donning, doffing, disposing, and PPE use according to a level area. On these questions, the options provided were never (1), sometimes (2), often (3), and always (4). The third section of the questionnaire consisted of 18 questions about factors that influence compliance. In this section, the participants may answer in four-point scales (1-strongly disagree, 2disagree, 3-agree, 4-strongly agree). The four scales were converted into a two-scale format for descriptive interpretation as disagree (strongly disagree and disagree) and agree (strongly agree and agree).

The content validity of the questionnaire was tested by some experts. Construct validity test was done with Pearson's correlation. The r-values for questions about donning, doffing, disposing, and PPE use according to a level area were 0.938, $0.806,0.904$, and $0.904(\mathrm{p}<0.01)$, respectively. Internal consistency with Cronbach $\alpha$ was used for the reliability test. In the reliability test of the 22 questions in the questionnaire, the Cronbach alpha value was 0.635 ( $\mathrm{r}$ table 0.444 ); thus, the questionnaire was reliable.

\section{Ethical Consideration}

General Hospital Dr. Saiful Anwar Malang's ethics committee regarding the protection of human rights and welfare in medical research has carefully reviewed the research protocol and approved this study (Ethical Approval Number: 400.218/K.3/302/2020). We treated all participants' data with confidentiality.

\section{Data processing and analysis}

Data from google spreadsheet were entered and analyzed using SPSS version 25 . The data were analyzed descriptively (frequency, percentages, mean and median) to explore the pattern of participants' compliance in using PPE. We defined the compliance based on their maximum score from the four questions, which was 16. The participants with a score less than 16 were categorized as non-compliant. The Chi-square test was applied to differentiate the level of compliance between two groups, and binary logistic regression was used to analyze factors that may influence the compliance.

\section{RESULTS AND DISCUSSIONS \\ Demographic characteristics}

The participants involved in this study were 165 non-medical health care professionals, including 31 pharmacists, 68 pharmacy technicians, 37 nutritionists, and 29 radiographers (Table I). Most of them were female (84.8\%), aged less than 40 years. The majority of them $(80.6 \%)$ worked at non-Covid wards. Almost one-fifth of the participants did not know their working-level area. The level of workplace was defined according to the Indonesian Ministry of Health regulation about protective equipment use for COVID-19 (Kementerian Kesehatan RI, 2020). Level 1 workplace is a low-risk place with no direct contact with COVID-19 patients, does not handle infectious material, and does not provide direct services to patients. Level 2 is moderate risk places, no direct contact with patients under supervision or confirmed COVID-19 or infectious material but provide administrative services. Level 3 is high-risk places, no direct contact with patients under supervision or confirmed Covid-19 but have contact with infectious materials and provide direct services to patients. Level 4 is highrisk places, have direct contact with patients under the supervision or confirmed Covid-19, contact with infectious material, and provide direct services to patients (Kementerian Kesehatan RI, 2020).

\section{Compliance in using PPE}

The majority of participants answered 'always' in all questions about compliance. According to the level area, the participants who answered always donning, doffing, dispose, and use PPE were 83.6\%, 80.0\%, 87.9\%, and $80.0 \%$, respectively (Table 2 ). The median score was $16(4-16)$. Participants who had total scores of 16 were categorized as compliant, while those with a total score less than 16 were classified as non-compliant. In this study, the compliance rate was $67.3 \%$. The compliance rate among pharmacists, pharmacy technicians, nutritionists, and radiographers were $54.9 \%, 64.7 \%, 81.1 \%$, and $69.0 \%$, respectively (Table III). 
Table I. The Characteristics of Participants $(\mathrm{N}=165)$

\begin{tabular}{|c|c|c|c|}
\hline Characteristics & & $\mathbf{n}$ & $\%$ \\
\hline \multirow[t]{2}{*}{ Gender } & Male & 25 & 15.2 \\
\hline & Female & 140 & 84.8 \\
\hline \multirow[t]{5}{*}{ Age } & $\leq 30$ years old & 59 & 35.8 \\
\hline & $31-40$ years old & 69 & 41.8 \\
\hline & $41-50$ years old & 22 & 13.3 \\
\hline & $>50$ years old & 15 & 9.1 \\
\hline & Median (range) & 33 & $(23-57)$ \\
\hline \multirow[t]{4}{*}{ Profession } & Pharmacist & 31 & 18.8 \\
\hline & Pharmacy Technician & 68 & 41.2 \\
\hline & Nutritionist & 37 & 22.4 \\
\hline & Radiographers & 29 & 17.6 \\
\hline \multirow[t]{2}{*}{ Workplace } & Non-Covid19 ward & 133 & 80.6 \\
\hline & Covid19 ward & 32 & 19.4 \\
\hline \multirow[t]{5}{*}{ Level of workplace* } & Level 1 & 16 & 9.7 \\
\hline & Level 2 & 48 & 29.1 \\
\hline & Level 3 & 58 & 35.2 \\
\hline & Level 4 & 14 & 8.5 \\
\hline & Do not know & 29 & 17.6 \\
\hline \multirow[t]{2}{*}{ Employment status } & Contract employee & 116 & 70.3 \\
\hline & Civil servant & 49 & 29.7 \\
\hline \multirow[t]{5}{*}{ Working experience } & Less than 5 years & 40 & 24.2 \\
\hline & $5-10$ years & 57 & 34.5 \\
\hline & $10-15$ years & 34 & 20.6 \\
\hline & $15-20$ years & 9 & 5.5 \\
\hline & More than 20 years & 25 & 15.2 \\
\hline
\end{tabular}

Notes: * = working-level area were defined based on Indonesian Ministry of Health regulation (Kementerian Kesehatan RI, 2020)

Table II. Compliance in using personal protective equipment

\begin{tabular}{lcccc}
\hline Questions & Always (\%) & Often (\%) & Sometimes (\%) & Never (\%) \\
\hline Donned PPE properly before work & $138(83.6)$ & $21(12.7)$ & $5(3)$ & $1(0.6)$ \\
Removed PPE properly after finished work & $132(80.0)$ & $29(17.6)$ & $2(1.2)$ & $2(1.2)$ \\
Disposed PPE according to the hospital guidelines & $145(87.9)$ & $15(9.1)$ & $4(2.4)$ & $1(0.6)$ \\
Used PPE according to the level area of work & $132(80.0)$ & $27(16.4)$ & $5(3)$ & $1(0.6)$ \\
\hline
\end{tabular}

Table III. Total compliance score among participants

\begin{tabular}{lccc}
\hline The summed compliance & Frequency & Percent \\
\hline Median (range) & & $16(4-16)$ & \\
Non-compliant (less than 16) & 54 & & 32.7 \\
Compliant (equal to 16) & 111 & & 67.3 \\
\hline
\end{tabular}

Notes: The compliance score was obtained by summing the four questions about compliance. The participants with a score less than 16 were categorized as non-comply. Otherwise, participants with a score equal to 16 were categorized as comply. 
Table IV. Analysis between participant's characteristics and compliance in using PPE

\begin{tabular}{|c|c|c|c|c|}
\hline Characteristics & & Non-compliant (\%) & Compliant (\%) & p-value \\
\hline \multirow[t]{2}{*}{ Gender } & Male & $7(13)$ & $18(16.2)$ & $0.584^{*}$ \\
\hline & Female & $47(87)$ & $93(83.8)$ & \\
\hline \multirow[t]{2}{*}{ Age } & $\leq 33$ years old & $34(63)$ & $53(47.7)$ & $0.066^{*}$ \\
\hline & $>33$ years old & $20(37)$ & $58(52.3)$ & \\
\hline \multirow[t]{4}{*}{ Profession } & Pharmacist & $14(25.9)$ & $17(15.3)$ & \\
\hline & Pharmacy technician & $24(44.4)$ & $44(39.6)$ & $0.068^{* *}$ \\
\hline & Nutritionist & $7(13)$ & $30(27)$ & \\
\hline & Radiographer & $9(16.7)$ & $20(18)$ & \\
\hline \multirow[t]{2}{*}{ Working place } & Non-COVID & 48 (88.9) & $85(76.6)$ & $0.061 *$ \\
\hline & COVID & $6(11.1)$ & $26(23.4)$ & \\
\hline \multirow{5}{*}{$\begin{array}{l}\text { Working-level } \\
\text { area*** }^{* *}\end{array}$} & Level 1 & $9(16.7)$ & $7(6.3)$ & $0.004 *$ \\
\hline & Level 2 & $11(20.4)$ & 37 (33.3) & \\
\hline & Level 3 & $18(33.3)$ & $40(36)$ & \\
\hline & Level 4 & $1(1.9)$ & $13(11.7)$ & \\
\hline & Do not known & $15(27.8)$ & $14(12.6)$ & \\
\hline \multirow{7}{*}{$\begin{array}{l}\text { Employment } \\
\text { status } \\
\text { Working } \\
\text { experience }\end{array}$} & Hospital & $40(74.1)$ & $76(68.5)$ & $0.460 *$ \\
\hline & Government & $14(25.9)$ & $35(31.5)$ & \\
\hline & Less than 5 years & $16(29.6)$ & $24(21.6)$ & $0.031^{* *}$ \\
\hline & $5-10$ years & 21 (38.9) & $36(32.4)$ & \\
\hline & $10-15$ years & $12(22.2)$ & $22(19.8)$ & \\
\hline & $15-20$ years & $2(3.7)$ & $7(6.3)$ & \\
\hline & More than 20 years & $3(5.6)$ & $22(19.8)$ & \\
\hline
\end{tabular}

Notes: (p-value was obtained from chi-square test $(*)$ and Mann Whitney u test $\left({ }^{* *}\right)^{* * *}=$ working-level area was defined based on Indonesian Ministry of Health regulation (Kementerian Kesehatan RI, 2020).

Factors that may influence the compliance in using PPE

We further analyzed the sociodemographic characteristics of the participants that may associate with the compliance levels. Based on professions, the pharmacist has the lowest level of compliance rate among other professions, although this difference was not statistically significant $(p=0.068)$. There were significant differences in working-level area and experience between noncompliant and compliant groups. Participants who did not know the work level area tend to not comply with the use of PPE (27.8 vs. $12.6 \%$, $\mathrm{p}=0.004)$. Participants who had work experience of more than 20 years tend to comply with PPE (19.6 vs. 5.6\%). Inversely, participants who had fewer than five years of work experience tend to not comply with the use of PPE (29.6 vs. 21.6\%) (Table IV).

We also analyzed some other factors related to organizational, individual, and environmental factors that may influence participants' compliance. In univariate analysis, organizational, individual, and environmental factors significantly influenced compliance. The organizational factors included the difficulty to use PPE, lack of training program, and regular monitoring. The individual factors related to the compliance included unsure about the benefit of PPE and uncomfortable feelings. The environmental factor that influences the compliance included the co-worker's role in promoting PPE. The difficulty in donning, doffing, and PPE disposal significantly influenced compliance (2.83 (0.730-3.478, $\mathrm{p}=0.025$ ) (Table V).

Our recent study showed that $67.3 \%$ of nonmedical health professionals complied in using PPE. More than $80 \%$ of the participants answered always donning, doffing, dispose, and using PPE according to the level area designated by hospital regulation. This result was higher than another publication. A study in China conducted during the H1N1 pandemic showed that only $18 \%$ of respondents correctly identified all PPE components, and 55\% reported high compliance (>80\%) with PPE use during patient care. In this study, they included medical doctors, nurses, and other professionals in the analyses (Hu et al., 2012). 
Table V. Factors influencing the compliance to PPE use

\begin{tabular}{|c|c|c|c|}
\hline \multirow{2}{*}{ Factors } & \multicolumn{2}{|c|}{ p-value } & \multirow{2}{*}{ OR (95\% CI) } \\
\hline & Univariate & Multivariate & \\
\hline \multicolumn{4}{|l|}{ Organization factors } \\
\hline Availability of PPE procedures. & 1 & - & - \\
\hline Difficulty to use PPE. & $<0.0001^{*}$ & $0.025^{*}$ & $2.843(1.138-7.102)$ \\
\hline Lack of training program & $0.007^{*}$ & 0.242 & $1.594(0.730-3.478)$ \\
\hline Regular monitoring & $0.038^{*}$ & 0.173 & $0.564(0.247-1.285)$ \\
\hline Lack of punishment & 0.195 & - & - \\
\hline Availability of PPE & $0.028^{*}$ & 0.497 & $0.675(0.217-2.101)$ \\
\hline $\begin{array}{l}\text { The number of PPE in the work area does } \\
\text { not always match the needs }\end{array}$ & $0.010^{*}$ & 0.100 & $1.930(0.882-4.223)$ \\
\hline \multicolumn{4}{|l|}{ Individual factors } \\
\hline Fear of catching an infections & 1.000 & - & - \\
\hline Afraid to infect the family & 1.000 & - & - \\
\hline Afraid to infect the patient & 0.243 & - & - \\
\hline Fear of being punished & 0.954 & - & - \\
\hline Unsure about the benefit of PPE & $0.039^{*}$ & 0.415 & $0.743(0.363-1.519)$ \\
\hline Increasing workload perception & 0.608 & - & - \\
\hline Uncomfortable in wearing PPE & 0.054 & 0.442 & $2.665(0.219-32.354)$ \\
\hline \multicolumn{4}{|l|}{ Environmental factors } \\
\hline Co-workers do not use PPE & 0.122 & - & - \\
\hline Co-workers never remind to use PPE & $0.024^{*}$ & 0.729 & $1.265(0.334-4.789)$ \\
\hline The presence of posters about Covid-19 & 0.445 & - & - \\
\hline Family support & 0.095 & 0.180 & $0.250(0.033-1.897)$ \\
\hline
\end{tabular}

Notes: p-value was obtained from a binary logistic test; p-value marked with an asterisk $\left(^{*}\right)$ indicates a statistically significant value.

Katanami et al. conducted an observational study at a third referral hospital in Japan through video monitoring. This study showed that the adherence rate to appropriate PPE use was 34\%. The nurses and the nursing assistant's adherence rate was low compared to infectious disease doctors and cleaning staff (27.9 vs. 100 and $85.7 \%$ ). This study showed that medical engineering, pharmacists, and other professionals had the lowest adherence (7,7\%) (Katanami et al., 2018).

Comparing the compliance between healthcare professionals who worked in covid and non-covid areas showed a difference but not statistically significant. Participants who worked at covid ward tend to comply in using PPE (23.4 vs. 11.1\%, p=0.061). A study from Neuwirth et al. (2020) supported this finding. The overall adherence to using PPE was significantly higher among HCWs who worked at covid ward than noncovid ward (Neuwirth et al., 2020). 26 of 32 (81.25\%) of our participants who work at covid ward complied using PPE. This result was higher than nurse compliance at a private hospital in
Malang (less than 60\%) (Gunawan \& Chalidyanto, 2020).

Our recent study demonstrated that lack of knowledge about work area level and lower work experience was associated with a decrease in compliance. A good understanding of the work area level is vital because staff who know the work area's level will understand the types of PPE used. Thus they use PPE appropriately, not overuse or misuse (Cook, 2020). Good knowledge and accumulation of experience during work had a significant correlation to compliance (Gunawan \& Chalidyanto, 2020). These findings support that regular training to increase the knowledge may be able to change their behavior in using PPE.

Our study demonstrated that organizational factors, such as difficulty to use PPE, lack of training program and regular monitoring, the availability of PPE in the hospital, and the supply of PPEs matching the demand influenced the compliance. The difficulties in using PPE may be due to inappropriate PPE sizes, the PPE design, and its complexity for use (Fan et al., 2020). Lack of 
training program may correlate with poor knowledge. A study in Japan conducted among 735 nurses at 28 tertiary hospitals demonstrated that a lack of knowledge on standard precaution as the critical component to avoid infection significantly decreased PPE compliance (Morioka et al., 2020). Furthermore, the evaluation of knowledge among nurses in the intensive care unit in Yogyakarta showed that only $60 \%$ of the nurse had high knowledge about PPE use guidelines (Cahyaning Pramesti, 2017). Another study in Northern Uganda showed that $23.7 \%$ of nurses, nursing aides, cleaners, and doctors do not know how to donning and doffing PPE. $13.6 \%$ of them do not use PPE even when indicated (Okello et al., 2017). This finding implies that the hospital management should perform routine training for their staff about the proper use of PPE.

The other organizational factor that influenced compliance in using PPE was the availability of PPE. The requirement and availability of PPE were imbalanced during the pandemic. Thus, the strategy to procure and supply a good-quality PPE may increase compliance (Sharma et al., 2020).

The individual factors that influence compliance were uncertainty about the effectiveness of PPE and the feeling of discomfort when using PPE. Perceived PPE effectiveness has a strong correlation with compliance. Some Hospital staff felt uncertain about the quality and effectiveness of PPE. A review conducted by Brooks et al. showed that using PPE may induce discomfort. They reported several symptoms associated with the use of PPE, such as dehydration, skin desquamation, shortness of breath, sweating, dizziness, headaches, and skin rashes. The use of PPE may decrease healthcare service quality, making it challenging to communicate with patients due to muffled speech, inability to establish non-verbal cues with patients, and making them less 'visible' to their patients (Brooks et al., 2020).

An environmental factor that influenced the compliance in using PPE found in this study was the co-worker's role in reminding PPE. Brooks et al. (2020) conducted a meta-analysis of 36 studies to identify factors associated with compliance with social and behavioral infection control measures among healthcare staff. This study showed noncompliant colleagues or managers were associated with non-compliant employees. They thought that the compliance of their colleagues might increase their compliance. They also believed that the manager should give an example and also encourage the employee to use PPE (Brooks et al., 2020).

\section{STRENGTH AND LIMITATION}

Our current study is the first study that evaluates the compliance among non-nurses or non-doctors healthcare professionals. We involved non-medical healthcare professionals included pharmacists, pharmacy technicians, nutritionists, and radiographers. These groups of healthcare professionals also had a similar risk to COVID-19 infection compared to doctors and nurses. The limitation in this study may come from the methods of gathering data. We used self-administered questionnaires without direct observation. This method may result in over-reporting of the compliance in using PPE. However, in this current situation, direct observation in the hospital was not recommended as it may increase the risk of viral transmission.

\section{CONCLUSION}

The practical problem, including the difficulty in using PPE and regular monitoring, plays a significant role in the non-medical healthcare professionals' compliance in using PPE. This finding suggests that regular training about the proper use of PPE and regular monitoring may increase compliance.

\section{ACKNOWLEDGEMENTS}

The authors acknowledge Saiful Anwar General Hospital for funding this research. The authors thank all pharmacy staff, nutritionists, and radiographers who participated in this study.

\section{REFERENCES}

Bielicki, J. A., Duval, X., Gobat, N., Goossens, H., Koopmans, M., Tacconelli, E., \& van der Werf, S. (2020). Monitoring approaches for healthcare workers during the COVID-19 pandemic. The Lancet Infectious Diseases, 20(10), e261-e267. https://doi.org/10.1016/S14733099(20)30458-8

Brooks, S., Greenberg, N., Wessely, S., \& Rubin, G. J. (2020). Factors affecting healthcare workers' compliance with social and behavioural infection control measures during emerging infectious disease outbreaks: Rapid evidence review.

https://doi.org/10.1101/2020.05.27.20114 744 
Cahyaning Pramesti, A. (2017). Evaluation of Knowledge and Compliance of Nurses on The Use Personal Protective Equipment (PPE) in Intensive Care Unit (ICU) RSUD Panembahan Senopati Bantul Yogyakarta. Jurnal Medicoeticolegal Dan Manajemen Rumah Sakit, 6(3), 187-193. https://doi.org/10.18196/jmmr.6144

Cook, T. M. (2020). Personal protective equipment during the coronavirus disease (COVID) 2019 pandemic - a narrative review. Anaesthesia, 75(7), 920-927. https://doi.org/10.1111/anae.15071

Erdem, H., \& Lucey, D. R. (2021). Healthcare worker infections and deaths due to COVID-19: A survey from 37 nations and a call for WHO to post national data on their website. International Journal of Infectious Diseases, 102, 239-241. https://doi.org/10.1016/j.ijid.2020.10.064

Fan, J., Jiang, Y., Hu, K., Chen, X., Xu, Q., Qi, Y., Yin, H., Gou, X., \& Liang, S. (2020). Barriers to using personal protective equipment by healthcare staff during the COVID-19 outbreak in China. Medicine, 99(48), e23310. https://doi.org/10.1097/MD.00000000000 23310

Gunawan, I., \& Chalidyanto, D. (2020). Analysis of Determinant Factors for Hospital Staff Adherence to the Use of PPE the Care of COVID-19 Patients. 9(December 2019), 187194.

Houghton, C., Meskell, P., Delaney, H., Smalle, M., Glenton, C., Booth, A., Xhs, C., Devane, D., Lm, B., Houghton, C., Meskell, P., Delaney, H., Smalle, M., Glenton, C., Booth, A., Xhs, C., Devane, D., \& Lm, B. (2020). Barriers and facilitators to healthcare workers' adherence with infection prevention and control (IPC) guidelines for respiratory infectious diseases: a rapid qualitative evidence synthesis (Review). Cochrane Database of Systematic Reviews, 4, CD013582.

https://doi.org/10.1002/14651858.CD013 582.www.cochranelibrary.com

Hozhabri, H., Sparascio, F. P., Sohrabi, H., Mousavifar, L., Roy, R., Scribano, D., De Luca, A., Ambrosi, C., \& Sarshar, M. (2020). The global emergency of novel coronavirus (SARS-CoV-2): An update of the current status and forecasting. International Journal of Environmental Research and Public Health, 17(16), 1-35. https://doi.org/10.3390/ijerph17165648

Hu, X., Zhang, Z., Li, N., Liu, D., Zhang, L., He, W., Zhang, W., Li, Y., Zhu, C., Zhu, G., Zhang, L., Xu, F., Wang, S., Cao, X., Zhao, H., Li, Q., Zhang, X., Lin, J., Zhao, S., ... Du, B. (2012). SelfReported Use of Personal Protective Equipment among Chinese Critical Care Clinicians during 2009 H1N1 Influenza Pandemic. PLOS ONE, 7(9), 3-9. https://doi.org/10.1371/journal.pone.0044 723

Jahawir Gustav Rizal. (n.d.). Sudah 507 Nakes Meninggal karena Covid-19, Terbanyak di Bulan Desember Halaman all - Kompas.com. Retrieved January 15, 2021, from https://www.kompas.com/tren/read/2020 /12/29/130000965/sudah-507-nakesmeninggal-karena-covid-19-terbanyak-dibulan-desember?page=all

Katanami, Y., Hayakawa, K., Shimazaki, T., Sugiki, Y., Takaya, S., Yamamoto, K., Kutsuna, S., Kato, Y., \& Ohmagari, N. (2018). Adherence to contact precautions by different types of healthcare workers through video monitoring in a tertiary hospital. Journal of Hospital Infection, 100(1), 70-75. https://doi.org/10.1016/j.jhin.2018.01.001

Kementerian Kesehatan RI. (2020). Penggunaan Alat Pelindungan Wabah COVID-19. Penggunaan Alat Pelindungan Wabah COVID-19, April, 1-27.

Morioka, S., Tajima, T., Sugiki, Y., Hayakawa, K., \& Ohmagari, N. (2020). Adherence to personal protective equipment use among nurses in Japanese tertiary care hospitals: what determines variability? Journal of Hospital Infection, 104(3), 344-349. https://doi.org/10.1016/j.jhin.2019.11.019

Neuwirth, M. M., Mattner, F., \& Otchwemah, R. (2020). Adherence to personal protective equipment use among healthcare workers caring for confirmed COVID-19 and alleged non-COVID-19 patients Meike. Antimicrobial Resistance \& Infection Control, 1-5. https://doi.org/10.21203/rs.3.rs-42553/v1 Offeddu, V., Yung, C. F., Low, M. S. F., \& Tam, C. C. (2017). Effectiveness of Masks and Respirators Against Respiratory Infections in Healthcare Workers: A Systematic Review and Meta-Analysis. Clinical Infectious Diseases, 65(11), 1934-1942. https://doi.org/10.1093/cid/cix681

Okello, T. R., Kansime, K., Odora, J., Apio, J. A., \& Pecorella, I. (2017). Barriers and factors 
affecting personal protective equipment usage in St. Mary's Hospital Lacor in Northern Uganda. East and Central African Journal of Surgery, 22(1), 59. https://doi.org/10.4314/ecajs.v22i1.8

Organisation, W. H. (2020). WHO DirectorGeneral's Opening Remarks at The Media Briefing On COVID-19 - 11 March 2020. In WHO Director General's Speeches (Issue March, p. 4). https://www.who.int/directorgeneral/speeches/detail/who-directorgeneral-s-opening-remarks-at-the-mediabriefing-on-covid-19---11-march-2020

Santoso, K. H. (2019). RENCANA STRATEGIS (RENSTRA) RSUD Dr. SAIFUL ANWAR MALANG. 2.

Sasongko, D. (n.d.). RSSA Malang Tambah Fasilitas Layanan Khusus Bagi Pasien Covid-19 / merdeka.com. Retrieved January 15, 2021, from

https://www.merdeka.com/peristiwa/rssa -malang-tambah-fasilitas-layanan-khususbagi-pasien-covid-19.html

Sharma, N., Hasan, Z., Velayudhan, A., M. A, E., Mangal, D. K., \& Gupta, S. D. (2020). Personal Protective Equipment: Challenges and Strategies to Combat COVID-19 in India: A Narrative Review. Journal of Health Management, 22(2), 157-168. https://doi.org/10.1177/09720634209355 40
Tejada, J., \& Punzalan, J. (2012). On the misuse of Slovin's formula. The Philippine Statistician, 61(1), 129-136

STPC19. (2021). Peta Sebaran | Satgas Penanganan COVID-19. In Https://Covid19.Go.Id/PetaSebaran (p. ). https://covid19.go.id/petasebaran

Verbeek, J. H., Rajamaki, B., Ijaz, S., Sauni, R., Toomey, E., Blackwood, B., Tikka, C., Ruotsalainen, J. H., \& Kilinc Balci, F. S. (2020). Personal protective equipment for preventing highly infectious diseases due to exposure to contaminated body fluids in healthcare staff. The Cochrane Database of Systematic Reviews, 5, CD011621. https://doi.org/10.1002/14651858.CD011 621.pub5

WHO. (2020). Rational use of personal protective equipment for coronavirus disease 2019 (COVID-19) and considerations during severe shortages. Who, April, 1-28. https://apps.who.int/iris/handle/10665/3 31695

World Health Organisaton. (2020). COVID-19 Weekly Epidemiological Update Global summary. November, 1-22. https://www.who.int/emergencies/disease s/novel-coronavirus-2019/situationreports/ 